\title{
Soluble Vascular Cell Adhesion Molecule 1
}

National Cancer Institute

\section{Source}

National Cancer Institute. Soluble Vascular Cell Adhesion Molecule 1. NCI Thesaurus.

Code C92533.

The determination of the amount of soluble vascular cell adhesion molecule 1 present in a sample. 